\title{
The 'Cost' of Climate Change: How Carbon Emissions Allowances \\ are Accounted for Amongst European Union Companies
}

by

\author{
Peter Warwick \\ Chew Ng* \\ Department of Accounting, Finance \& Economics \\ Griffith Business School \\ Griffith University
}

\begin{abstract}
Following the withdrawal of IFRIC 3: Emissions Rights in 2005, European Union (EU) companies participating in an Emissions Trading Scheme (ETS) do not have definitive guidelines as to how to account for carbon emissions allowances. Using a content analysis methodology, this study examines disclosed accounting policies of companies participating in the EU ETS, and reveals how, in the absence of clear guidance, they account for their carbon emissions allowances. As the accounting method adopted will impact upon a company's financial statements, these findings would be of interest to accounting standards setters, investors, financial reporting preparers, auditors, and academic audiences.
\end{abstract}

Keywords: IFRIC 3, Emissions Trading Scheme, emissions allowances, and accounting policy choices

JEL classification: $\quad$ M41

\footnotetext{
* Corresponding author: Chew $\mathrm{Ng}$, Department of Accounting, Finance and Economics, Griffith Business School, Griffith University, Nathan Campus, Queensland 4111, Australia, telephone: +61 7 3735 6492, facsimile: +61 73735 3719, e-mail: c.ng@griffith.edu.au
} 
The 'Cost' of Climate Change: How Carbon Emissions Allowances

are Accounted for Amongst European Union Companies

\begin{abstract}
Following the withdrawal of IFRIC 3: Emissions Rights in 2005, European Union (EU) companies participating in an emissions trading scheme (ETS) do not have definitive guidelines as to how to account for carbon emissions allowances. Using a content analysis methodology, this study examines disclosed accounting policies of companies participating in the EU ETS, and reveals how, in the absence of clear guidance, they account for their carbon emissions allowances. As the accounting method adopted will impact upon a company's financial statements, these findings will be of interest to accounting standards setters, investors, financial reporting preparers, auditors, and academic audiences.
\end{abstract}




\section{The 'Cost' of Climate Change: How Carbon Emissions Allowances are Accounted for Amongst European Union Companies}

The Intergenerational Report 2010 (Australian Government 2010) identifies climate change as the largest threat to Australia's environment and one of the most significant challenges to its economic sustainability. To tackle this challenge/threat, the former Rudd government committed to implementing a cap-and-trade scheme, called the Carbon Pollution Reduction Scheme (CPRS) in $2013^{1}$, targeting a $5 \%$ reduction in emissions below 2000 levels by 2020 on a unilateral basis. Although the demise of the Rudd government in June 2010 and a subsequent hung parliament have created uncertainties over this initiative, the Gillard government announced In February 2011 that a carbon tax regime will be introduced as from July 1 2012, with the implementation of a CPRS in 2015.

Globally, thirty-two countries are currently operating, or are participating within, an emissions trading scheme (ETS), with other major economies moving towards the adoption of such a scheme (Australian Government 2010). To date, the European Union Emissions Trading System (EU ETS) is the largest multi-country and multi-sector scheme in the world. In 2008, of the total of 8.2 billion metric tonnes of carbon allowances (worth €92 billion or US\$125 billion) traded globally, the EU ETS accounted for two-thirds of the global volume and three-quarters of global value (Point Carbon 2010: 5). With such material amounts involved, the way in which EU companies account for their carbon emissions allowances in their financial statements has also taken on greater significance.

However, since the withdrawal of the international accounting guidance, commonly referred to as IFRIC 3: Emission Rights, there has been no formal 
accounting recommendation as to how emissions are to be financially accounted for within a cap-and-trade emissions trading scheme. As noted in Deloitte (2009), EU companies therefore have a degree of accounting policy choice in defining what kind of asset an 'emissions allowance' is - intangible asset or inventory, and how it is valued - at cost or fair value.

The purpose of this study is to gain an empirical understanding of how carbon emissions allowances are accounted for by EU companies operating under the EU ETS. Examining approaches to accounting for emissions allowances is important since the financial implications arising from the EU ETS may be material in nature and amount. As mentioned previously, the EU ETS is the largest carbon market segment in the world. Since the EU ETS is an important mechanism for carbon reductions, an investigation of the way in which these companies account for their impact would provide useful information to governments, regulators, and other stakeholders. With the globalisation of ETS on the horizon, the accounting treatments of emissions allowances adopted by EU companies will also have increasing international relevance.

Currently academic research studies in this area are scant, though various organisations (including the Association of Chartered Certified Accountants, ACCA, and the International Emissions Trading Association, IETA) and Big 4 accounting firms have published a number of reports in the area. For example, PricewaterhouseCoopers in conjunction with IETA in 2007 surveyed 26 European companies and identified six main accounting approaches to emissions allowances. Ernst and Young (2008) found that of 32 companies investigated, 20 reported using some form of the net liability approach and 22 companies recognised emissions 
allowances as intangible assets. In a study conducted for ACCA and in conjunction with IETA, Lovell et al. (2010) found that most of the companies they surveyed were not following IFRIC 3. To the best of our knowledge, the present study is probably the first academic research in the area undertaken in 2009. Our findings would be of interest to accounting standards setters, investors, financial statement preparers, auditors and the academic community, not only in Europe, but in any country presently participating, or about to participate, in their version of an emissions trading scheme.

The remainder of this paper proceeds as follows. The next section introduces the EU ETS. This is followed by a discussion of the accounting treatments for emissions allowances. Our research questions are then raised. An outline of the type of analysis to be undertaken and the sample selection are followed. We then analyse and interpret our results. The paper concludes with a discussion on the implications of the findings, limitations of the study, and possible future research avenues.

\section{EU Emissions Trading Scheme}

The Kyoto Protocol provides legally binding commitments for signatory countries to reduce greenhouse gases (GHG). To achieve the EU target of $20 \%$ emissions reduction from 1990 levels by 2020, a cap-and-trade emissions trading scheme was established and became operational as from 1 January 2005. Under the scheme, an overall emissions limit (i.e. cap) was initially set by each EU member state. The cap is converted into allowances (called European Union Allowances, or EUAs) which companies are required to obtain to cover the annual carbon emissions from their 
'installations'. ${ }^{2}$ A fixed amount of allowances are allocated free of charge, by the 'scheme administrators' (i.e. the governmental bodies of the EU member states), to account holders of operator companies responsible for the installation's activities. The account holders must report the quantity of independently verified emissions to the scheme administrators for each calendar year by 31 March of the following year. For each tonne of carbon emissions produced, the account holder must surrender one EUA to the scheme administrator by 30 April of that year. This obligation may be satisfied through the surrender of appropriate numbers of EUAs matching the verified actual emissions. Financial penalties apply for non-compliance. Taking into account the number of EUAs held and their obligations to surrender EUAs for their emissions obligations, companies are free to buy and sell their EUAs in the actively traded ETS market. This process represents a market-based response by the EU to provide financial incentives for companies to curtail emissions (Bebbington and Larrinaga-Gonzalez 2008).

The EU ETS consists of three compliance periods (Robinson 2010). The first phase, operating from 2005 to 2007, was designed to serve as a learning phase. During this period, the infrastructure of a carbon market was built and member states were required to allocate at least $95 \%$ of the allowances free of charge.

The second phase started at the beginning of 2008 and will run until the end of 2012, coinciding with the first commitment phase of the Kyoto Protocol. During this period, at least $90 \%$ of the allowances must be allocated free of charge. A penalty of $€ 100$ for every tonne of emissions that does not have matching allowances is also imposed. 
Phase 3 of the scheme will commence in 2013 and run until 2020. During this period, the emissions cap will be set at a European level rather than by each member state individually (Robinson 2010). Under Directive 2009/29/EC of the European Parliament, more auctioning of allowances (carried out individually by EU member states) is planned, with a target of 70\% being auctioned by 2020 .

In addition to meeting emissions obligations, account holders may hold emissions allowances for speculative trading purposes. Prices of emissions allowances have been volatile over the past three years (Capoor and Ambrosi 2009), with a high of $€ 28$ on the spot market in July 2008 to a low of $€ 8$ in February 2009. In May 2010 , emissions allowances were trading between $€ 10$ and $€ 15$. The existence of tradable emissions allowances creates further challenges for accountants as in principle these allowances should be treated as a financial commodity and be recognised in the accounts and reported in the financial statements (Bebbington and Larrinaga-Gonzalez 2008).

\section{Accounting for Emissions Allowances}

Before we examine the issue of how EU companies are to account for EUAs, it is useful to review the accounting treatments for pollution allowances in the United States in the 1990s. This is because some of the accounting guidance as stated in IFRIC 3 appears to have been based on existing literature relating to accounting treatments for pollution allowances in the US.

In March 1993, the Federal Energy Regulatory Commission (FERC) issued financial reporting requirements for pollution allowances created under the Clear Air 
Act amendments of 1990. The FERC recommended that pollution allowances should be recorded according to their intended use and at historical cost. Allowances used to cover pollution emissions are reported as inventory in the 'Allowance Inventory' account, while allowances intended for use as investments are recorded in the 'Other Investments' account. Since allowances issued by the Environmental Protection Agency (EPA) were free of charge, under a historical cost accounting system, no assets or expenses were recognised. Only purchased allowances would be recorded as assets (according to the intended use) and an expense would be recognised when they were used to compensate for pollution emissions (Wambsganss and Sanford 1996: 645).

However, Wambsganss and Sanford (1996) argued that the above accounting treatments were inconsistent. They recommended that issued pollution allowances should be treated as donated assets and be valued at market price. Doing so would provide a uniform accounting treatment for all allowances, regardless of whether they are granted or purchased. Wambsganss and Sanford (1996) also argued that pollution allowances are intangible assets and should be valued at market price or fair value.

As the discussion in the following section reveals, the subsequent accounting guidance on emissions allowances recommended by the International Accounting Standards Board (IASB) appeared to adopt Wambsganss and Sanford's view (Bebbington and Larrinaga-Gonzalez 2008: 705). 


\section{IFRIC Interpretation 3: Emission Rights}

An ETS raises the issue of whether and how to recognise emissions allowances and the obligation to deliver allowances. In the run-up to the launch of the EU ETS, the International Accounting Standards Board (IASB) instructed the International Financial Reporting Interpretations Committee (IFRIC) to develop accounting guidance for emissions allowances. In December 2004, IFRIC issued IFRIC Interpretation 3: Emission Rights (known as IFRIC 3) which was to be applicable for financial reporting periods beginning on or after 1 March 2005, with earlier adoption encouraged so that it could be implemented for the beginning of Phase 1 of the EU ETS. IFRIC 3 recommended that emissions allowances (an asset) be treated separately from the obligation to deliver allowances (a liability) arising under the EU ETS. This approach is referred to as a 'gross' basis (ACCA 2009: 7).

\section{Emissions Allowances}

IFRIC 3 first considered whether emissions allowances (granted and purchased) were assets and concluded that they met the definition of assets. They then examined the nature of these allowances and decided that they were intangible assets and not financial instruments. Since they are intangible assets, IFRIC 3 recommended that, regardless of whether emissions allowances have been allocated free of charge or purchased, they should be treated in accordance with IAS 38 Intangible Assets (equivalent to AASB 138). Under this standard, financial statement preparers may adopt one of the two alternatives for subsequent measurement of intangibles: the cost method or the revaluation method. With a cost method, intangibles are subsequently measured at cost less amortisation and impairment. Since a 
revaluation model can only be adopted where intangibles are traded in an active market, EUAs will meet this requirement. Under this approach, emissions allowances are carried at fair value, with gains recognised under 'Equity' in the balance sheet as a revaluation surplus and the increase in the revaluation surplus included in the statement of comprehensive income as an item of 'other comprehensive income'.

IAS 38 is also explicit that intangible assets held for sale in the ordinary course of business (such as trading) are to be accounted for as inventory in accordance with IAS 2 Inventories (equivalent to AASB 102).

If emissions allowances were issued at less than fair value (as mentioned previously, the bulk of allowances until now have been allocated free of charge), IFRIC 3 recommended that these allowances be initially measured at their fair value, with the difference between the fair value and the amount paid be identified as a government grant and accounted for under IAS 20 Accounting for Government Grants and Disclosure of Government Assistance (equivalent to AASB 120). The granted allowances should be classified as deferred income in the balance sheet and subsequently released to income on a systematic basis over the compliance period for which these allowances were issued. However, IAS 20 also allows companies to choose an accounting policy whereby the emissions allowances can be recognised at a 'nominal amount' (that is zero value).

\section{Emissions Liability}

IFRIC 3 deemed that the obligation to deliver allowances equivalent to actual emissions to the scheme administrator was a liability which must be treated as a 'provision' within the scope of IAS 37 Provisions, Contingent Liabilities and 
Contingent Assets (equivalent to $A A S B$ 137). It recommended that an emissions liability should be measured at the best estimate at the end of the reporting period of the expenditure required to settle the present obligation. This will usually be the fair value or market value of the number of allowances required to compensate for emissions made throughout the calendar year, and payable to the scheme administrators by the end of April in the following calendar year. Changes in the value of a company's obligation to surrender allowances to the scheme administrator were recognised in the income statement.

Under IFRIC 3, offsetting (i.e. netting off) the intangible asset (i.e. emissions allowances held) and the emissions obligation (i.e. to deliver emissions allowances to the value of emissions produced) is not permitted.

\section{Accounting Mismatches within the IFRIC 3}

However IFRIC 3 met with strong resistance upon its release. The main reason for the objection of this accounting guidance was due to the existence of accounting mismatches (see, for example, Bebbington and Larrinaga-Gonzalez 2008, Cook, 2009, MacKenzie 2009, amongst others). Critics of IFRIC 3 argued that the adoption of a gross basis approach to account for emissions allowances and liabilities constitutes a balance sheet/income statement mismatch (or reporting mismatch). This is because changes as a result of any revaluation of emissions allowances were recognised under equity in the balance sheet, while gains or losses derived from the valuation of emissions liability were reported in the income statement. This mismatch may lead to potential volatility in the reported income. 
Additionally, the use of different accounting values (cost versus fair value) to measure assets, some measured on recognition at cost and others at fair value, also create a measurement mismatch (see, for example, Bebbington and LarrinageGonzalez 2009; and Deloitte 2009).

Another mismatch relates to timing of recognition. Under IFRIC 3, emissions allowances are recognised when they are acquired (in most cases at the commencement of the calendar year) while the emissions liability is recognised as emissions occur throughout the calendar year (Ernst \& Young 2009).

These mismatches led to the European Financial Reporting Advisory Group (EFRAG) to conclude that following IFRIC 3 would result in an artificial volatility of earnings in EU companies, and consequently issued a negative endorsement advice (Bebbington and Larrinaga-Gonzalez 2008: 705). In June 2005, at the request of the European Commission, the IASB withdrew the interpretation, despite continuing to consider IFRIC 3 to be the most appropriate guidance. Since then alternative approaches have been presented as guidance in both the professional (ACCA 2009, Delloite 2009, Dellaportas 2008, amongst others) and academic literature (Cook 2009). The IASB and FASB are currently working on a joint project to address emissions accounting and final guidance is not expected until late 2012.

\section{Possible Approaches to Accounting for Emissions Allowances}

The withdrawal of IFRIC 3 means that there is no authoritative accounting guidance within International Financial Reporting Standards (IFRS) explicitly for accounting for emissions allowances. Under the hierarchy for selecting accounting policies in IAS 8 Accounting Policies, Changes in Accounting Estimates and Errors (equivalent to AASB 
108), companies may develop their own accounting policies for cap-and-trade emissions schemes as long as they are consistent with underlying IFRS. Paragraph 10 of IAS 8 requires that management should use their judgment in developing and implementing an accounting policy which results in financial information that is relevant and reliable (sub-paragraphs $a$ and $b$ ).

The application of IAS 8 would mean that the issues involving accounting for emissions allowances would be guided by several existing international accounting standards, including IAS 2 Inventories (if emissions allowances are held for sale in the ordinary course of business); IAS 20 Accounting for Government Grants and Disclosure of Government Assistance; IAS 37 Provisions, Contingent Liabilities and Contingent Assets; IAS 38 Intangible Assets; and IAS 39 Financial Instruments: Recognition and Measurement (if emissions allowances are held for trading purposes). The application of these accounting standards in accordance with IAS 8 would result in numerous accounting polices that are available to companies.

In the absence of authoritative accounting guidance, Dellaportas (2008, 64 5) identified three possible approaches to accounting for emissions allowances. They are: (1) the IFRIC 3 approach, (2) the net liability approach, and (3) the government grants approach. Under the net liability approach, granted emissions are recognised at nil value if granted for free (this accounting policy choice is permitted under the IAS 20) and the entity only recognises a liability once actual emissions (measured in terms of a number of emissions allowances) exceed the granted emissions allowances on hand. The shortfall is measured at the market price. The net liability approach is specifically prohibited under IFRIC 3. The government grant approach derives from the application of IAS 20. The emission liability under this approach is 
recognised as incurred. However, unlike IFRIC 3, the liability is measured by reference to the carrying amount of those granted emissions allowances held that are used to settle the obligation. Only the shortfall will be measured at the market value.

\section{Research Questions}

Since empirical evidence of these accounting approaches are still scant, the present study aims to gain an insight into how EU companies are accounting for emissions allowances in the absence of definitive guidance. Specifically, we ask the following research questions:

1. How do companies recognise granted emissions allowances, upon initial receipt and subsequently in the balance sheets?

2. How are purchased emissions allowances recognised? and

3. How are the liabilities for emissions recognised?

At the same time, however, it is also expected that due to the lack of clear guidance, many companies may choose to either not disclose their accounting policy choices in full, or instead may choose to only disclose some of their accounting treatments.

\section{Research Methodology}

\section{Content Analysis}

To understand how companies participating in the EU ETS are accounting for carbon emissions allowances, a content analysis (Krippendorff, 1980) is employed in this 
study, examining company accounting policies or procedures disclosed in their publicly prepared annual reports ${ }^{3}$. Content analysis is 'a systematic, objective, and quantitative procedure for summarising the content of written, recorded, or published communication' (Colton and Covert, 2007: 235). It involves 'codifying qualitative and quantitative information into pre-defined categories in order to derive patterns in the presentation and reporting of information' (Guthrie and Abeysekera, 2006: 120). For content analysis to be effective, Guthrie and Abeysekera (2006) argued that certain technical requirements, especially the unit of analysis, should be met.

\section{Unit of Analysis}

Using this methodology, the unit of analysis is the 'content' of some form of communication text, and refers to, for example, the words, sentences, themes, sections or pictures within that text after it has been produced (Walter 2006, Haslam and McGarty 2003). In the accounting literature, when a content analysis is adopted researchers either count the number of disclosures or examine the extent (or volume) of disclosures (Gray, et al. 1995). The present study concentrates on the number of particular accounting policies adopted by EU companies in relation to accounting for emissions allowances.

The unit of analysis being examined through content analysis in this study is publicly available annual reports. While surveys or questionnaires could also be used as alternative means of gathering information, annual reports represent an audited (externally verified) source of information that is easily and efficiently accessed (downloaded from company websites). Additionally, annual reports are a primary 
source of obtaining data for analysis in the accounting literature, and most research that uses content analysis in accounting research uses annual reports (see, for example, Bae and Sami, 2004, and Searcy and Mentzer 2003).

\section{Coding of Emissions Related Accounting Disclosures}

To simplify analysis, the identified relevant sections within each annual report were electronically copied from the downloaded annual report (electronic file) to a Word document (in tabular format) for coding purposes. This required some reformatting. A copy of the summarised relevant disclosures for Fortum is provided in Appendix 1. These documents were printed and combined to form one centralised 'book' ${ }^{4}$. The next step was to commence coding of these documents. This coding process was undertaken in two phases.

From the background literature, derived research questions had highlighted the importance of gaining an understanding of how companies account for 'granted emissions allowances' (research question 1); 'purchased emissions allowances', (research question 2); and 'provisions' or 'liabilities' for carbon emissions (research question 3). However, for each of these themes, two important aspects were recognised: how the company classified the transaction in terms of its specific asset or liability categorisation, and the value that the company assigned to the specific asset or liability. To make coding simple, an alphanumeric code was assigned to each accounting disclosure relevant to one of the research questions. The number assigned simply matched the research question number. If the disclosure referred to the asset or liability category, the letter ' $A$ ' was assigned; and if the valuation of the transaction was provided, the letter ' $\mathrm{B}$ ' was assigned. For example, a company may 
provide the following statement: 'Purchased $\mathrm{CO}_{2}$ emissions allowances are initially recognised at cost (purchase price) within intangible assets'. As this disclosure is relevant to research question 2 , the statement 'Purchased $\mathrm{CO}_{2}$ emissions allowances are initially recognised at cost (purchase price) ...' was assigned the code '2B', while the statement 'Purchased $\mathrm{CO}_{2}$ emissions allowances are initially recognised ... within intangible assets' was assigned the code ' $2 A$ '.

The responses provided for each assigned alphanumeric code were then combined together to make response sheets for the second coding phase. An example of responses by all companies for alphanumeric code ' $1 A$ ' is provided in Appendix 2. These responses were then grouped according to similarity in accounting treatment, and coded using one or a few words that summarised that treatment. Hence, for alphanumeric code ' $1 A^{\prime}$ ', concerning the asset classification of granted emissions allowances, four main responses were observed, and the following coded terms: 'intangible asset', 'inventory', 'asset' and 'not disclosed' were assigned. The absence of information can also be informative, and as such the term 'not disclosed' was assigned when a company did not disclose an accounting treatment ${ }^{5}$. To overcome some of the methodological limitations associated with content analysis, especially the reliability and subjectivity issues (Ryan and $\mathrm{Ng} 2000$ ), coded disclosures were checked by the other author. This approach is consistent with the suggestion made by Guthrie and Abeysekera (2006). Having now assigned codes for disclosures from each company matching this study's research questions, each code was assigned a categorical number, and the data was entered into an SPSS database for analysis. 


\section{Sample Firms}

\section{Sample Selection}

The sample selection process involved two stages of planning. The first stage of this process was to determine the database that would be used to select sample companies. Due to resource constraints, only publicly available databases were considered for selection. After assessing several potential databases, the Carbon Monitoring for Action (CARMA) database was selected. This database is financed by the Centre for Global Development, which according to McGann (2009) was ranked fifteen, out of several thousand research organisations, among the world's top 'think tanks' (Centre for Global Development 2009). A search on CARMA's database produced a list of over 9,000 companies ranked from highest to lowest carbon emitting companies in Europe. From this population the 250 highest ranked carbonemitting companies were selected as the sample for this study.

A random sampling technique has not been selected for two reasons. Firstly, observation of the website has revealed that many of the companies at the lower end of the list are stated as producing zero carbon emissions (mainly renewable energy producing companies), and hence are less likely to disclose financial information about how they account for emissions allowances. Secondly, the value of emissions allowances of larger emitters may be material in accounting terms and thus requires recognition. In pursuit of paragraph 10 of the IAS 8, management of higher emitters are required to use their judgement in developing and applying an accounting policy which results in information that is relevant and reliable. Materiality is a sub-concept of relevance under the IASB Framework. Following this 
reporting requirement, we only selected the 250 highest emitting companies in the database for our study.

Having identified these companies, our next sample selection process was to choose a calendar year for this study. The 2007 financial year annual reports of these companies were selected for study for three reasons. First, 2007 was the last year of the first phase of the EU ETS. We believe that by the end of the first phase, companies would have developed and applied their accounting policy to account for emissions allowances. Second, the 2007 financial year annual reports were the most recent reports available at the time of data collection (this study was conducted in the first half of 2009). Third, the present study is an exploratory research, with the aim of revealing insights into how EU highest carbon emitters, in the absence of any formal reporting guidelines, are accounting for emissions allowances.

Having decided the year for study, attempts were made to identify these 250 companies' websites, to download an electronic copy of each company's 2007 annual report. While all companies were required to produce financial statements for the 2007 financial year, companies have the discretion as to determining the start and finishing dates for that financial year. For example, some companies' financial years start on 1 January and finish on 31. December, while other companies' financial year interval covers a different range. The annual reports used in this study comprise all available financial statements that were purported by the companies' websites to be for their 2007 financial year. To derive a suitable set of disclosures for inclusion in this study's analysis, the following selection criteria must be met: the annual reports must (1) be in English, in other words, non-English reports were 
excluded; (2) be publicly available on the relevant website; and (3) disclose the accounting treatment of emissions allowances.

\section{Descriptive Statistics of the Sample Firms}

Table 1 illustrates how the portion of companies' annual reports analysed in this study was derived. Of the 250 companies examined in this study, 47 companies $(18.8 \%)$ provided annual reports meeting the sample selection criteria. The remaining 203 companies were excluded for the following reasons: 14 companies (5.6\%) provided annual reports for the 2007 financial year, in English, but did not have any disclosures for the accounting treatment of emissions allowances relevant to this study; 65 companies (26\%) did not have a website, or if so, did not provide an annual report for the 2007 financial year; 40 companies (16\%) were confirmed or believed to be subsidiary companies of other companies, and did not provide separate annual reports; 16 companies (6.4\%) provided annual reports for the 2007 financial year, but not in English; 28 companies (11.2\%) provided websites in a language other than English and 40 companies (16\%) were excluded because they report outside the EU.

\section{[INSERT TABLE 1 ABOUT HERE]}

Table 2 shows the representation of companies from each country in both the sample of 250 companies, and the group of 47 companies providing accounting disclosures that were examined in this study through content analysis. As can be seen in this table, of the $27 \mathrm{EU}$ countries, 25 are represented in the sample, enabling accounting practices across almost all countries to potentially be included in this 
study's analysis. Comparing the list of countries included in the sample with the countries included in the analysis reveals that of the 25 countries represented in the sample, 17 countries were found to have companies with accounting disclosures relevant for this study. Hence, although only $18.6 \%$ of companies' annual reports were analysed in this study, 17 out of 27 countries (63\%) are represented. A high proportion of companies represented in the analysis adds validity when drawing conclusions from this study, in summarising how EU countries are accounting for carbon emissions allowances. Interestingly, although Poland is represented by 32 companies in the top 250 carbon emitting companies, none of these companies met the requirements for inclusion in the sample. The main reason for exclusion of Polish companies in particular was that the websites for the majority of these companies could not be found, or if found, it was evident that no annual report was available. This reason was in fact the most common reason for excluding companies from the sample across all countries.

\section{[INSERT TABLE 2 ABOUT HERE]}

\section{Data Analysis and Discussion}

Having identified 47 companies' annual reports that satisfied the sample selection criteria, downloaded copies of these annual reports (in Adobe pdf format) were printed and read to identify and isolate only disclosures pertaining to accounting policy treatments of carbon emissions allowances and obligations. These accounting policies were in most cases disclosed within the 'notes to the financial statements' 
sections. Different terms were used to identify the emissions allowances, including 'emissions allowances', ' $\mathrm{CO}_{2}$ allowances' and so on.

To confirm that all relevant disclosures had been identified for inclusion in the analysis, electronic searches within the pdf annual reports were undertaken, using the 'Search' function within these Adobe files (selecting 'Edit', then 'Search'). This function presents, for each vocabulary term typed in, a listing of all instances where the word(s) is present within the electronic file. These confirmatory searches included, for example, the words 'emission', 'carbon', ' $\mathrm{CO}_{2}$ ' etc, having recognised such terms as being frequently used to refer to the emissions allowances across all the annual reports. Each instance in a list shows the placement of the relevant term in the sentence, and the page within the document is identified by placing the mouse pointer over each listed reference item. These identified sentences and pages were matched with previously observed (and highlighted) disclosures in the printed annual reports.

\section{Accounting for Carbon Emissions}

As this study is an exploratory study to gain an initial understanding of how companies in the European Union are accounting for carbon emissions allowances, presentation of the findings in frequency tables is considered sufficient to illustrate these trends.

\section{Granted Emissions Allowances}

The content analysis of annual report disclosures for the receipt of granted emissions allowances reveals that most companies (55.3\%) are treating these transactions as 
an intangible asset (see Table 3). This is higher than that reported in Lovell et al. (2010). Consistent with Lovell et al. (2010), only a few companies treated granted allowances as inventory (or 6.4\%), or in one case, the asset classification was unspecified. However, more than a third (36.2\%) of the companies in the analysis did not disclose an accounting method for the receipt of granted emissions allowances. Given that our sample comes from the highest ranked carbon emitters, one would expect that the value of emissions allowances would be material. One possible explanation for this non-disclosure is because there is no clear accounting guidelines for treatments of granted emissions allowances as a consequence of the withdrawal of IFRIC 3.

\section{[INSERT TABLE 3 ABOUT HERE]}

While granted emissions allowances are predominantly classified as intangible assets, the methods of valuing these allowances are much more varied. In some cases, slight differences in wording across company disclosures represented potential ambiguity in the coding of these valuation methods. For example one company may disclose that it values granted emissions at 'nil value', another company states 'nominal value' (which infers an actual value, but lower than market value), and another company may specify 'nominal value (nil)'. This ambiguity is further illustrated in the use of the term 'token amount' by two companies, which may or may not mean the same as 'nominal amount'. In cases of ambiguity, separate codes were assigned, creating a total of seven different coded responses. In other cases discretionary judgement was made by the researchers to allocate a code. 
The analysis revealed (see Table 4) that the most frequently occurring method of valuing these granted emissions allowances upon initial receipt was the recording of a 'nil' value ( $38.3 \%$ companies). Market value (or fair value) was the next most frequent assigned valuation (21.3\% of companies). $23.4 \%$ of companies did not disclose a method of valuation.

\section{[INSERT TABLE 4 ABOUT HERE]}

\section{Purchased Emissions Allowances}

Companies participating in the EU ETS may purchase emissions allowances usually for one of two reasons: (1) If they anticipate that their annual emissions may be greater than allowances held to cover their obligations; (2) they hold emissions allowances for trading on the open market (for example in forward contracts, swaps, derivatives trading etc). A review of the disclosures made revealed that the main reason companies purchased emissions allowances was to meet their emissions obligations. Only a few companies disclosed that they also participated in trading activities. In pursuit of IAS 38, traders who hold emissions allowances for sale in the ordinary course of business are to be accounted for as inventory in accordance with IAS 2. Under IAS 39, these emissions allowances are to be valued at fair value with gains and losses recognised to the income statement.

Since most of our sample firms held emissions allowances to meet their emissions obligations, the present study only examined purchase of emissions allowances for this purpose. To this end, care was taken during coding to ensure that the disclosures relating to the company's intended use of the purchased allowances 
were correctly coded. In cases where companies did not specify the intended use, discretionary judgment was made considering the context of the disclosure.

The analysis reveals that of 29 companies that did disclose a valuation for purchased allowances upon initial receipt, 28 of these companies recorded them at cost (purchase price), whereas one company recorded them at fair value (Table 5). This predominant trend for the recording of purchased emissions allowances (an asset) upon receipt at cost price is consistent with the historical cost convention.

\section{[INSERT TABLE 5 ABOUT HERE]}

While statements concerning the initial recording of purchased allowances are quite consistent, statements regarding the valuation of purchased allowances at the end of the reporting period reveal an opposite trend. For only nine companies that disclosed a subsequent valuation method for purchased allowances, seven different responses were observed, and each was given a separate code (see Table 6). This finding is quite informative. It reveals that at the end of the reporting period, due to the lack of definitive guidelines, there is clearly a lack of consistency amongst companies as to how they should account for these purchased emissions allowances. The lack of guidance as to how to account for this transaction, and inconsistent practices being used by companies, may be a contributing factor into why the nondisclosure rate for this item is so high, particularly, as can be observed in Table 5, that a much higher proportion of companies (a total of 29 companies) disclosed that they had purchased emissions allowances. 


\section{[INSERT TABLE 6 ABOUT HERE]}

\section{Liability for Released Emissions}

Companies participating in the EU ETS are liable to surrender to their scheme administrator one emissions allowance for each tonne of carbon emissions generated during the year. As the surrender of allowances occurs after a few months into the next financial year, IAS 37 requires companies to recognise the obligation to deliver allowances equivalent to actual emissions as a provision. Table 7 demonstrates that the majority of companies (78.7\%) recognised this obligation as a provision or liability. However, two companies (or 4.3\%) did not follow IAS 37 and only booked the payment as an expense when emissions liability was settled.

\section{[INSERT TABLE 7 ABOUT HERE]}

In the absence of clear guidance since the withdrawal of IFRIC 3, a company may account for emissions allowances held as an asset at one value, and the measurement of the obligation to surrender those same allowances at a different valuation. The analysis revealed that companies attribute two separate valuations for this obligation: the value of emissions allowances held at the end of the reporting period (which may be in the form of granted and/or purchased emissions allowances), and secondly, if insufficient allowances are held to meet the known or estimated obligation, the value of the emissions allowances required to meet the shortfall. Table 8 shows that 21 companies (44.7\%) disclose how the portion of the obligation to be paid is measured in terms of emissions allowances held at the end of the reporting period. These disclosures revealed 11 different accounting methods for 
this valuation. Due to varying descriptive styles that companies used to explain their valuation method, different codes were assigned to each description. Overall, the obligation to surrender emissions allowances in terms of emissions allowances held appears to be measured most frequently at either the cost of purchased allowances, or at their carrying amount.

\section{[INSERT TABLE 8 ABOUT HERE]}

In regard to how companies account for the value of emissions allowances required to meet the shortfall, again a range of accounting policies was disclosed, and again slight wording differences (which may or may not refer to a distinctly different accounting policy) were coded separately. For example, thirteen companies (27.7\%) stated that they measure the remaining portion of the obligation as 'the market price at the balance sheet (or reporting) date' (see Table 9). Two companies however stated this amount as the market price up to the balance sheet (or reporting) date'. This may or may not have the same meaning. To illustrate, another company (2.1\%) measured the obligation as the average price for the three months preceding the end of the reporting period. Hence the words 'up to' may refer to consideration of the market price of emissions allowances being publicly traded over a period of time prior to the end of the reporting period, rather than 'at' the end of the reporting period. Table 9 does also illustrate that in most cases the market price of the publicly traded emissions allowances was used (though measured at potentially different trading dates). 


\section{[INSERT TABLE 9 ABOUT HERE]}

\section{Concluding Remarks, Implications, Limitations and Future Research}

The purpose of this study was to gain an understanding of how companies within the EU ETS are accounting for their carbon emissions allowances in 2007. We found that there was generally no uniformity of accounting for emissions allowances. Indeed, large emitting companies operating in the EU ETS adopted a diversity of accounting practices to account for their emissions allowances. We found that these companies tended to report:

1. granted emissions allowances as intangible assets, with a nil value recorded upon receipt;

2. purchased emissions allowances initially at cost price, but without any clear trend for their subsequent reporting at the end of the reporting period;

3. the obligation to deliver allowances to their national authorities as a provision (or liability) at either the carrying amount or the purchase cost for allowances held at the end of the reporting period; and the amount outstanding at the market price at the end of the reporting period.

Consistent with Lovell et al. (2010), we found that our sample firms generally departed from IFRIC 3. For example, most companies measured the granted allowances at nil value, while IFRIC 3 recommended the fair value should be used. Company disclosures relating to the recognition of the obligation to surrender emissions allowances as a provision was consistent with the IFRIC 3 approach. 
Although IFRIC 3 recommended measuring this provision at the best estimate at the end of the reporting period, our sample companies generally measured the allowances held at purchase price (which may or may not be the best estimate), and their residual obligation at market value.

The findings of our study have some important implications for accounting standards setters, policy makers such as government and other regulators, credit rating agencies, investors, and financial analysts. Firstly, although IASB publicly defended IFRIC 3 as 'an appropriate interpretation' of existing accounting standards, it also acknowledged that the document 'creates unsatisfactory measurement and reporting mismatches' ${ }^{6}$. IFRIC 3 approached the accounting for emissions allowances by separately considering the nature of the allowances granted and the obligation to pay for emissions by delivering allowances (Cook 2009). From a conceptual point of view, emissions allowances are an asset under the IASB Framework for the Preparation and Presentation of Financial Statements since allowances are controlled by the entity as a result of past events and from which future economic benefits are expected flow to the entity. However, when considered whether emissions allowances are a financial instrument or an intangible asset, IFRIC 3 decided that they were intangible assets and recommended that they should be treated in accordance with $I A S 38^{7}$ and measured initially at their fair value, with the difference between fair value and amount paid identified as a government grant and accounted for under IAS 20. Regarding the emissions liability, IFRIC 3 deemed that the obligation to deliver allowances equivalent to actual emissions was a liability and treated as a provision under IAS 37. Regardless of whether these treatments were theoretical sound and were consistent with the conceptual framework the IASB 
encountered significant criticisms from regulators and companies. However, Cook (2009: 465) urged standards setters to resist the temptation to resolve each accounting issue by establishing a standalone standard, but rather to develop a clear application of a principle in the conceptual framework.

Secondly, the lack of definitive accounting guidance has resulted in a wide range of different accounting practices being used amongst companies operating under the EU ETS. As a result, comparability of company performance is problematic, if not impossible. Robinson (2010) discusses the way in which Moody's deal with the different accounting practices, including the removal of gains and cash flows arising from the sale of emissions allowances since they consider these as non-recurring in nature. Finally, the absence of a standard or interpretation also makes an auditor's task of providing assurance difficult. However, it should be pointed out the International Auditing and Assurance Standards Board has just issued an Exposure Draft, entitled ISAE 3410 Assurance Engagements on Greenhouse Gas Statements, for comments.

Notwithstanding the above, a number of limitations may have contributed to the findings possibly not being representative for all companies participating in the EU ETS. First, as an exploratory study, we examined the data from one year only. Consequently, meaningful conclusions may not be drawn from the findings. Second, the study required that company annual reports had to be in an English version for inclusion in the analysis. Hence it is possible that reports prepared in a foreign language may contain disclosures that illustrate a different trend. Third, although considerable attempts were made to identify the websites and annual reports for every company in this study's population, other reports unable to be accessed may 
also show a different trend to the findings presented here. Fourth, the use of a content analysis approach may also result in bias as researchers may be required at times to make some subjective judgments during the analysis process. Similar to prior studies (see, for example, Bae and Sami 2004), no test for the reliability of coding instrument was made in the study. Finally, although we previously justified the selection of sample firms, we acknowledge that the use of this non-random selection of higher emitters may be potentially biased.

Accounting for emissions allowances is a relatively new research area. This study has revealed that many companies are not disclosing their accounting policies for emissions allowances. As such future research could include surveys targeting companies that do not provide these disclosures in their annual reports, to gain a wider and deeper understanding of their accounting practices and the manager's reasonings for selecting those polices.

Both Peter Warwick and Chew Ng FCPA are at the Department of Accounting, Finance \& Economics, Griffith Business School, Griffith University. The authors wish to acknowledge the financial support of the Sustainable Business Research Initiative, Griffith Business School, Griffith University. They are also grateful to the constructive suggestions made by the two anonymous reviewers and the Editor.

\section{Notes}

1 Initially the target date was 2011. However, in April 2010, following two rejections in the Senate, the Rudd government announced the postponement of the CPRS until 2013.

2 Directive 2003/87/EC of the European Parliament defines the term 'installation' as 'a stationary technical unit where one or more activities listed in Annex 1 (of the Directive) are carried out ... which could have an effect on emissions and pollution'.

3 This study, as much as possible, used annual reports, as these represent audited publicly available company disclosures. Annual reports are well recognised as a suitable source of company disclosures in the accounting literature. However, in a few cases, companies did not have a publicly downloadable annual report, but rather had other documents (titled, for example, 'consolidated financial statements' or 'legal information') which contained their financial statements and disclosed accounting policies. If these other documents contained disclosures about the accounting for carbon emissions allowances, they were included in this study's analysis. Hence, for simplicity, any reference to 'annual reports' in this study also 
includes, in a few cases, these other documents containing relevant disclosures where an annual report had not been made available.

$4 \quad$ As all relevant statements had been summarised and collated into one central document, this assisted the analysis in several ways: (1) the coding of each statement within this 'book' became more efficient than if coding had been performed across many printed annual reports; (2) it improved the reliability that all relevant comments were included in the analysis, as the relevant disclosures had meticulously been isolated and copied into one document, and could be analysed statement by statement; (3) as it was relatively easy to quickly refer back through this one 'book' (as compared to looking back through several annual reports), it assisted in ensuring that subsequent coding was consistent in the assigning of codes to comments.

$5 \quad$ There are a number of reasons why companies may not disclose an accounting treatment. One example may be because the company did not incur the particular transaction, and therefore saw no need to state this. Interestingly some companies, on the other hand, provided disclosures of how they would account for a particular transaction, even if they did not incur the transaction.

6 International Accounting Standards Board, 'IASB withdraws IFRIC interpretation on Emission Rights', available from: http://www.iasplus.com/pressrel/0507withdrawifric3.pdf, last accessed 10 June 2011.

7 As pointed out by MacKenzie (2009: 449), by not treating emissions allowances as a financial instrument, companies could not adopt hedge accounting and provided no accounting recognition for carbon emissions if certain conditions were met. 
Appendix 1: Example of Extracted Corporate Disclosures for Subsequent Coding

\begin{tabular}{|c|c|}
\hline Fortum & Page \\
\hline $\begin{array}{l}\text { The Group accounts for emission allowances based on currently valid IFRS } \\
\text { standards where purchased emission allowances are accounted for as } \\
\text { intangible assets at cost, whereas emission allowances received free of } \\
\text { charge are accounted for at nominal value. } \\
\text { A provision is recognised to cover the obligation to return emission } \\
\text { allowances. } \\
\text { To the extent that Group already holds allowances to meet the obligation } \\
\text { the provision is measured at the carrying amount of those allowances. } \\
\text { Any shortfall of allowances held over the obligation is valued at the current } \\
\text { market value of allowances. } \\
\text { The cost of the provision is recognised in the income statement within } \\
\text { materials and services. } \\
\text { Gains from sales of emission rights are reported in other income. }\end{array}$ & 31 \\
\hline $\begin{array}{l}\text { Proprietary trading risks This Company is trading electricity forwards, } \\
\text { futures, options, and CfD's (contract for differences) mainly on the Nord Pool } \\
\text { market and } \mathrm{CO} 2 \text { allowances on the European market. }\end{array}$ & 40 \\
\hline $\begin{array}{l}\text { CO2 emission allowance price risk The Company manages its exposure to } \\
\text { CO2 allowance prices related to own production through the use of CO2 } \\
\text { forwards and by ensuring that the costs of allowances are taken into } \\
\text { account during production planning. } \\
\text { These are own use contracts valued at cost. } \\
\text { In addition to own production the Company has proprietary trading book. } \\
\text { These allowances are treated as derivatives in the accounts. } \\
\text { At } 31 \text { December } 2007 \text { the trading volumes of sold and bought CO2 emission } \\
\text { allowances were 3,101 ktCO2 (2006: } 405) \text { and 3,121 ktCO2 (2006: } 418) \text {. } \\
\text { The respective net fair values were EUR -13 million (2006:0) and EUR } 13 \\
\text { million (2006:0). }\end{array}$ & 40 \\
\hline $\begin{array}{l}\text { 11. Other Income Capital gains also includes gain on sale of emission rights } \\
\text { EUR } 39 \text { million (2006: } 10 \text { million). } \\
\text { Costs for made emissions which are not covered by emission rights received } \\
\text { for free were EUR } 0 \text { million (2006: } 10 \text { million). The costs are included in } \\
\text { Materials and services. }\end{array}$ & 53 \\
\hline Intangible Assets EUR million 20072006 Change in emission rights & 61 \\
\hline $\begin{array}{l}\text { Bought emission rights are recognised as intangible assets to the lower of } \\
\text { fair value and historical cost. } \\
\text { Emission rights received free of charge are accounted to nominal value. } \\
\text { The amount of emission rights in intangible assets is EUR } 0 \text { million (2006: } 9 \\
\text { million). }\end{array}$ & 61 \\
\hline
\end{tabular}




\section{Appendix 2}

Coded Disclosures for Q1 (A) - Includes companies with no disclosure for this issue

\begin{tabular}{|c|c|c|}
\hline Company & $\begin{array}{l}\text { Response Matching Research Q1: How do Companies recognise emissions allowances? } \\
\text { Q1A: (Sub question): Asset Category }\end{array}$ & Code \\
\hline 1 & 'Surplus quotas or certificates ... are booked to other intangible assets ...'. & Intangible asset \\
\hline 2 & (Not Stated) & Not Disclosed \\
\hline 3 & (Not Stated) & Not Disclosed \\
\hline 4 & $\begin{array}{l}\text { '... granted carbon allowances received in a period are initially recognised ... within intangible assets'. } \\
\text { 'Purchased carbon allowances are initially recognised ... within intangible assets'. }\end{array}$ & Intangible asset \\
\hline 5 & (Not Stated) & Not Disclosed \\
\hline 6 & (Not Stated) & Not Disclosed \\
\hline 7 & (Not Stated) & Not Disclosed \\
\hline 8 & (Not Stated) & Not Disclosed \\
\hline 9 & (Not Stated) & Not Disclosed \\
\hline 10 & '... emission rights held ... for the settlement of obligations are reported as intangible assets'. & Intangible asset \\
\hline 11 & $\begin{array}{l}\text { 'Other intangible assets also include greenhouse gas emission quotas purchased, which are not } \\
\text { amortized'. }\end{array}$ & Intangible asset \\
\hline 12 & 'Emission quotas (emission rights) are recognized as intangible assets ...'. & Intangible asset \\
\hline 13 & $\begin{array}{l}\text { 'The CO2 and greenhouse effect gas emission licences for own use and attributed for free are booked as } \\
\text { intangible assets...'. }\end{array}$ & Intangible asset \\
\hline 14 & 'Intangible assets ... CO2 emission certificates issued free by the government ...'. & Intangible asset \\
\hline 15 & $\begin{array}{l}\text { 'Purchased CO2 emission allowances are initially recognised at cost (purchased price) within intangible } \\
\text { assets'. }\end{array}$ & Intangible asset \\
\hline 16 & 'Emission allowances Emission allowances are recognised under inventories'. & Inventory \\
\hline 17 & 'The Group recognizes $\mathrm{CO} 2$ emission rights as non-amortizable intangible assets'. & Intangible asset \\
\hline 18 & (Not Stated) & Not Disclosed \\
\hline 19 & 'Emission allowances issued to ESB are recorded as intangible assets ...'. & Intangible asset \\
\hline 20 & $\begin{array}{l}\text { 'Inventories represent assets that are .... or used to manufacture products or perform services (raw } \\
\text { materials, auxiliary materials or fuels as well as purchased emission certificates)'. }\end{array}$ & Inventory \\
\hline 21 & (Not Stated) & Not Disclosed \\
\hline 22 & 'Emission rights acquired free of charge are valued in intangible assets at their market price ...'. & Intangible asset \\
\hline
\end{tabular}




\begin{tabular}{|c|c|c|}
\hline 23 & $\begin{array}{l}\text { 'The Group accounts for emission allowances ... where purchased emission allowances are accounted for } \\
\text { as intangible assets ...'. }\end{array}$ & Intangible asset \\
\hline 24 & (Not Stated) & Not Disclosed \\
\hline 25 & 'Emission rights have been categorised as stock assets'. & Inventory \\
\hline 26 & (Not Stated) & Not Disclosed \\
\hline 27 & 'The changes in 2007 and 2006 in intangible assets accounts ... Emission allowances ...'. & Intangible asset \\
\hline 28 & $\begin{array}{l}\text { 'CO2 emission rights ('allowances') are included in intangible fixed assets irrespective of their value and } \\
\text { useful life'. }\end{array}$ & Intangible asset \\
\hline 29 & 'An intangible asset is recognised on receipt of allocated emission allowances ...'. & Intangible asset \\
\hline 30 & (Not Stated) & Not Disclosed \\
\hline 31 & 'Emission allowances are recorded as an intangible asset within current assets ...'. & Intangible asset \\
\hline 32 & $\begin{array}{l}\text { 'The other non-current intangible assets item comprises concessions, permits and licences as well as } \mathrm{CO} 2 \\
\text { emission rights'. }\end{array}$ & Intangible asset \\
\hline 33 & $\begin{array}{l}\text { 'Emission allowances on } 31 \mathrm{Dec} 2007 \text { : Intangible assets include emission allowance assets totalling } € \\
125,000 \text { '. }\end{array}$ & Intangible asset \\
\hline 34 & 'Intangible assets include software and CO2 emission rights allowances'. & Intangible asset \\
\hline 35 & 'CO2 emission allowances are accounted for as intangible assets and reported under other assets'. & Intangible asset \\
\hline 36 & (Not Stated) & Not Disclosed \\
\hline 37 & 'The Group recognises carbon allowances granted as a current intangible asset ...'. & Intangible asset \\
\hline 38 & 'The Group has opted to record emission rights received, an intangible asset, ...'. & Intangible asset \\
\hline 39 & 'Emission rights which have been granted free of charge are accounted for as intangible assets ...'. & Intangible asset \\
\hline 40 & (Not Stated) & Not Disclosed \\
\hline 41 & $\begin{array}{l}\text { '... in which it has been allocated allowances to emit a fixed tonnage of carbon dioxide ... an intangible } \\
\text { asset for the allowances'. }\end{array}$ & Intangible asset \\
\hline 42 & '...emission rights are classified as inventories, as they are consumed in the production process'. & Inventory \\
\hline 43 & 'Carbon dioxide emissions allowances ... represent an intangible asset ...'. & Intangible asset \\
\hline 44 & (Not Stated) & Not Disclosed \\
\hline 45 & 'Purchased emission allowances are reported as intangible assets under current assets ...'. & Intangible asset \\
\hline 46 & $\begin{array}{l}\text { 'Emission rights ... are accounted for on the basis of the provisions of IAS } 38, I A S 20 \text { and IAS } 37 . \text { The } \\
\text { rights are recognized as assets at their fair value or at cost on the day of allocation or acquisition'. }\end{array}$ & Assets \\
\hline 47 & (Not Stated) & Not Disclosed \\
\hline
\end{tabular}




\section{References}

Association of Chartered Certified Accountants (ACCA), 2009, 'Emission Rights Accounting', Carbon Jigsaw Briefing, London.

Australian Government, 2010, 'Australian to 2050: Future Challenges', the 2010 Intergenerational Report, Printed by CanPrint Communications Pty Ltd.

Bae, B. and Sami, H., 2004, 'Firm Characteristics and Accounting Policy Choices for Environmental Liabilities', in C. F. Lee (ed), Advances in Quantitative Analysis of Finance and Accounting, 1: $235-65$.

Bebbington, J. and Larrinaga-Gonzalez, C., 2008, 'Carbon Trading: Accounting and Reporting Issues', European Accounting Review, 17, 4: 697 - 717.

Capoor, K., and P. Ambrosi, 2009, State and Trends of the Carbon Market 2009, the World Bank, Washington, D. C.

Centre for Global Development, 2009, About CGD, http://www.cgdev.org/section/about, last accessed 23 April 2009.

Colton, D., and Covert, R.W., 2007, Designing and Constructing Instruments for Social Research and Evaluation, John Wiley and Sons, San Francisco. 
Cook, A., 2009, 'Emission Rights: From Costless Activity to Market Operations', Accounting, Organizations and Society, 34: $456-68$.

Deloitte, 2009, Carbon Accounting Challenges: Are You Ready? http://www.deloitte.com/assets/Dcom-

UnitedStates/Local\%20Assets/Documents/Energy us er/us er NewChallengesinC arbonAccounting 1009.pdf, last accessed 20 January 2011.

Dellaportas, G., 2008, 'Accounting for Carbons', Charter, 79 5: $64-5$.

Ernst and Young, 2008, How are European Utilities Applying IFRS: An Overview of Financial Statements 2006, Global Utilities Centre, January.

Ernst and Young, 2009, Accounting for Emission Reductions and Other Incentive Schemes,

http://www.ey.com/Publication/vwLUAssets/Accounting emission reductions/\$SFI LE/Accounting emission reductions July09.pdf, last accessed 31 January 2011.

European Financial Reporting Advisory Group, 2005, Submission Paper to The European Commission, www.iasplus.com/efrag/0505ifric3endorsementadvice.pdf, last accessed 22 June 2009. 
Gray, R., Kouhy, R. and Lavers, S., 1995, 'Constructing a Research Database of Social and Environmental Reporting by UK Companies', Accounting, Auditing \& Accountability Journal, 8, 2: 78- 101.

Guthrie, J. and Abeysekera, I., 2006, 'Content Analysis of Social, Environmental Reporting: What is New?', Journal of Human Resource Costing \& Accounting, 10, 2: $114-26$

Haslam, S.A., and McGarty, C., 2003, Research Methods and Statistics in Psychology, SAGE Publications, London.

International Accounting Standards Board, 2004, IFRIC 3: Emission Rights (withdrawn in June 2005).

Krippendorf, K., 1980, Content Analysis: An Introduction to Its Methodology, SAGE Publications, London.

Lovell, H., de Aguiar, T. S., Bebbington, J. and Larrinaga-Gonzalez, C., 2010, Accounting for Carbon, ACCA and IETA.

McGann, J., 2009, 'The Think Tank Index', Foreign Policy Magazine, January, http://www.foreignpolicy.com/story/cms.php?story id=4598, last accessed 15 April 2009. 
MacKenzie, D. 2009, 'Making Things the Same: Gases, Emission Rights and the Politics of Carbon Markets', Accounting, Organisations and Society, 34: 440 - 55.

PricewaterhouseCoopers and International Emissions Trading Association, 2007, Trouble-Entry Accounting - Revisited, London.

PricewaterhouseCoopers and International Emissions Trading Association, 2010, Trouble-Entry Accounting - Revisited, London.

Robinson, P. 2010, 'Accounting for Emissions Allowances: Up in Smoke', Special Comment, Moody's Investors Service, October 27.

Ryan, C. and Ng, C., 2000, 'Public Sector Corporate Governance Disclosures: An Examination of Annual Reporting Practices in Queensland', Australian Journal of Public Administration, 59, 2: $11-23$.

Searcy D. L., and Mentzer, J.T., 2003, 'A Framework for Conducting and Evaluating Research', Journal of Accounting Literature, 22: 130 - 67.

Walter, M., 2006, Social Research Methods: An Australian Perspective, Oxford University Press, South Melbourne.

Wambsganss, J. R., and Sanford, B., 1996, 'The Problem with Reporting Pollution Allowances', Critical Perspectives on Accounting, 7: 643 - 52. 
Table 1

The Determining Reasons for the Inclusion of Sample Firms in the Analysis

\begin{tabular}{|l|c|c|c|}
\hline & Frequency & Percent & $\begin{array}{c}\text { Cumulative } \\
\text { Percent }\end{array}$ \\
\hline Accounting Disclosures Provided & 47 & 18.8 & 18.8 \\
Confirmed No Accounting Disclosures & 14 & 5.6 & 24.4 \\
$\begin{array}{l}\text { Difficulties: Website access or annual } \\
\text { report download }\end{array}$ & 65 & 26.0 & 50.4 \\
Confirmed Subsidiary & 40 & 16.0 & 66.4 \\
$\begin{array}{l}\text { Reports Downloaded, but in foreign } \\
\text { language }\end{array}$ & 16 & 6.4 & 72.8 \\
$\begin{array}{l}\text { Website in Foreign Language } \\
\text { Countries being reported to are not in } \\
\text { the European Union }\end{array}$ & 40 & 11.2 & 84.0 \\
\begin{tabular}{l} 
Total \\
\hline
\end{tabular} & 250 & 100.0 & 100.0 \\
\hline
\end{tabular}


Table 2

Countries Represented in the Sample, and Selected in the Study

\begin{tabular}{|l|c|c|c|c|}
\hline \multirow{2}{*}{ Country } & \multicolumn{2}{|c|}{$\begin{array}{c}\text { Companies across } \\
\text { sample (N=250) }\end{array}$} & \multicolumn{2}{c|}{$\begin{array}{c}\text { Companies selected } \\
\text { in this study (47) }\end{array}$} \\
\cline { 2 - 5 } & Frequency & $(\%)$ & Frequency & $(\%)$ \\
\hline Austria & 3 & 1.2 & 1 & 2.1 \\
\hline Belgium & 3 & 1.2 & - & - \\
\hline Bulgaria & 8 & 3.2 & - & - \\
\hline Cyprus & 1 & 0.4 & 1 & 2.1 \\
\hline Czech Republic & 10 & 4.0 & 3 & 6.4 \\
\hline Denmark & 2 & 0.8 & 1 & 2.1 \\
\hline Estonia & 1 & 0.4 & 1 & 2.1 \\
\hline Finland & 12 & 4.8 & 6 & 12.8 \\
\hline France & 5 & 2.0 & 1 & 2.1 \\
\hline Germany & 39 & 15.6 & 6 & 12.8 \\
\hline Greece & 1 & 0.4 & 1 & 2.1 \\
\hline Hungary & 6 & 2.4 & - & - \\
\hline Ireland & 3 & 1.2 & 2 & 4.3 \\
\hline Italy & 20 & 8.0 & 7 & 14.9 \\
\hline Latvia & 1 & 0.4 & - & - \\
\hline Lithuania & - & - & - & - \\
\hline Luxembourg & 1 & 0.4 & - & - \\
\hline Malta & 1 & 0.4 & 1 & 2.1 \\
\hline Netherlands & 9 & 3.6 & 3 & 6.4 \\
\hline Poland & 31 & 12.4 & - & - \\
\hline Portugal & 4 & 1.6 & 1 & 2.1 \\
\hline Romania & 3 & 1.6 & - & - \\
\hline Slovenia & 25 & 1.2 & 2 & 4.3 \\
\hline Slovakia & 25 & 14.6 & 3 & 6.4 \\
\hline Spain & & - & - & - \\
\hline Sweden & 30 & 16.0 & - & - \\
\hline United Kingdom & 100.0 & 47 & 100.0 \\
\hline Others (not in the EU ETS) & & & \\
\hline Total & 25 & - & - \\
\hline
\end{tabular}


Table 3

Recognition of Granted Emissions Allowances (Asset Type)

\begin{tabular}{|l|c|c|c|}
\hline & Frequency & Percent & $\begin{array}{c}\text { Cumulative } \\
\text { Percent }\end{array}$ \\
\hline Intangible Asset & 26 & 55.3 & 55.3 \\
\hline Inventory & 3 & 6.4 & 61.7 \\
\hline 'Asset' & 1 & 2.1 & 63.8 \\
\hline Not Disclosed & 17 & 36.2 & 100.0 \\
\hline Total & 47 & 100.0 & \\
\hline
\end{tabular}

Table 4

Method of Valuing Granted Emissions Allowances

\begin{tabular}{|l|c|c|c|}
\hline & Frequency & Percent & $\begin{array}{c}\text { Cumulative } \\
\text { Percent }\end{array}$ \\
\hline Nil Value & 18 & 38.3 & 38.3 \\
Market/Fair Value & 10 & 21.3 & 59.6 \\
Nominal Value & 3 & 6.4 & 66.0 \\
Quoted Price & 1 & 2.1 & 68.1 \\
Ad memoriam value & 1 & 2.1 & 70.2 \\
Replacement cost & 1 & 2.1 & 72.3 \\
Token Amount & 2 & 4.3 & 76.6 \\
Not Disclosed & 11 & 23.4 & 100.0 \\
Total & 47 & 100.0 & \\
\hline
\end{tabular}


Table 5

Initial Recording of Purchased Emissions Allowances

\begin{tabular}{|l|c|c|c|}
\hline & Frequency & Percent & $\begin{array}{c}\text { Cumulative } \\
\text { Percent }\end{array}$ \\
\hline At Cost (Purchase Price) & 28 & 59.6 & 59.6 \\
Market/Fair Value & 1 & 2.1 & 61.7 \\
Not Disclosed & 18 & 38.3 & 100.0 \\
Total & 47 & 100.0 & \\
\hline
\end{tabular}

Table 6

Subsequent Valuation of Emissions Allowances (End of the Reporting Period)

\begin{tabular}{|l|c|c|c|}
\hline & Frequency & Percent & $\begin{array}{c}\text { Cumulative } \\
\text { Percent }\end{array}$ \\
\hline Carried at Cost & 2 & 4.3 & 4.3 \\
$\begin{array}{l}\text { Measured at Fair value or, if lower } \\
\text { than carrying amount, written } \\
\text { down }\end{array}$ & 1 & 2.1 & 6.4 \\
Lower of cost or net realisable & 1 & 2.1 & 8.5 \\
value & 1 & 2.1 & 10.6 \\
Lower of fair value or historical \\
cost & 1 & 2.1 & 12.8 \\
Market value with a credit to & 2 & 4.3 & 17.1 \\
deferred income & 1 & 2.1 & 19.2 \\
At cost less any impairment losses & 38 & 80.8 & 100.0 \\
Measured at fair value & 47 & 100.0 & \\
Not Disclosed & & & \\
Total & 10.0 & \\
\hline
\end{tabular}


Table 7

Recognition of Emissions Obligations

\begin{tabular}{|l|c|c|c|}
\hline & Frequency & Percent & $\begin{array}{c}\text { Cumulative } \\
\text { Percent }\end{array}$ \\
\hline Provision/Liability & 37 & 78.7 & 78.7 \\
Expense & 2 & 4.3 & 83.0 \\
Not Disclosed & 8 & 17.0 & 100.0 \\
Total & 47 & 100.0 & \\
\hline
\end{tabular}

Table 8

Measurement of Emissions Allowances Held

\begin{tabular}{|c|c|c|c|}
\hline & Frequency & Percent & $\begin{array}{l}\text { Cumulative } \\
\text { Percent }\end{array}$ \\
\hline Cost of Purchased allowances & 5 & 10.6 & 10.6 \\
\hline Carrying amount of allowances & 6 & 12.8 & 23.4 \\
\hline $\begin{array}{l}\text { Acquisition cost (spot or forward } \\
\text { markets) }\end{array}$ & 2 & 4.3 & 27.7 \\
\hline Capitalised at cost & 1 & 2.1 & 29.8 \\
\hline Value initially recognised & 1 & 2.1 & 31.9 \\
\hline Pro rata basis, market value & 1 & 2.1 & 34.0 \\
\hline Balancing entry - token amount & 1 & 2.1 & 36.2 \\
\hline $\begin{array}{l}\text { Acquisition cost up to amount } \\
\text { purchased }\end{array}$ & 1 & 2.1 & 38.3 \\
\hline Net Liability method & 1 & 2.1 & 40.4 \\
\hline $\begin{array}{l}\text { Book value of allowances } \\
\text { capitalised }\end{array}$ & 1 & 2.1 & 42.6 \\
\hline $\begin{array}{l}\text { Cost of Purchased or Granted } \\
\text { allowances held }\end{array}$ & 1 & 2.1 & 44.7 \\
\hline Not Disclosed & 26 & 55.3 & 100.0 \\
\hline Total & 47 & 100.0 & \\
\hline
\end{tabular}


Table 9

Measurement of Emissions Allowance Outstanding

\begin{tabular}{|c|c|c|c|}
\hline & Frequency & Percent & $\begin{array}{c}\text { Cumulative } \\
\text { Percent }\end{array}$ \\
\hline Market price & 7 & 14.9 & 14.9 \\
\hline $\begin{array}{l}\text { Market price at end of the } \\
\text { reporting period }\end{array}$ & 13 & 27.7 & 42.6 \\
\hline $\begin{array}{l}\text { Market price up to end of the } \\
\text { reporting period }\end{array}$ & 2 & 4.3 & 46.8 \\
\hline $\begin{array}{l}\text { Net liability method, measured at } \\
\text { market price }\end{array}$ & 2 & 4.3 & 51.1 \\
\hline $\begin{array}{l}\text { Acquired emission reduction units } \\
\text { for some of liability }\end{array}$ & 1 & 2.1 & 53.2 \\
\hline $\begin{array}{l}\text { Current estimates of amounts } \\
\text { required }\end{array}$ & 2 & 4.3 & 57.4 \\
\hline $\begin{array}{l}\text { Average price for the } 3 \text { months } \\
\text { preceding the end of the } \\
\text { reporting period }\end{array}$ & 1 & 2.1 & 59.6 \\
\hline $\begin{array}{l}\text { Best estimate of amount required } \\
\text { to pay, then market price }\end{array}$ & 1 & 2.1 & 61.7 \\
\hline $\begin{array}{l}\text { Fair value - on the date financial } \\
\text { statements are filed }\end{array}$ & 1 & 2.1 & 63.8 \\
\hline Not disclosed & 17 & 36.2 & 100.0 \\
\hline Total & 47 & 100.0 & \\
\hline
\end{tabular}

